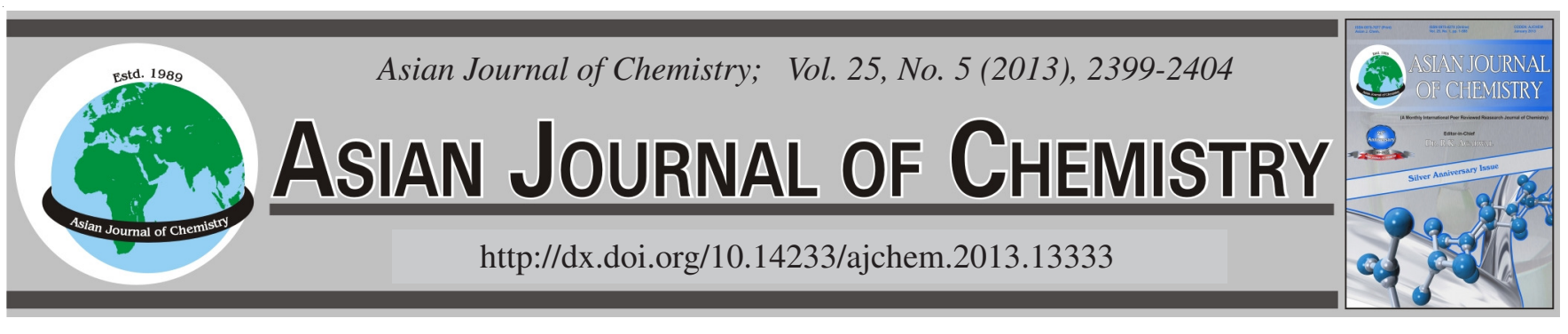

\title{
Removal of Lead(II) from Water by Adsorption on Novel Composites of Polyaniline with Maize Bran, Wheat Bran and Rice Bran
}

\author{
Farah Kanwal, Rabia Rehman*, Jamil Anwar and Muhammad SAeEd
}

Institute of Chemistry, University of the Punjab, Lahore-54590, Pakistan

*Corresponding author: Fax: +92 42 99230998; Tel: +92 42 99230463, Ext: 870; E-mail: grinorganic@yahoo.com

Polyaniline composites are gaining importance now-a-days for waste water treatment by adsorption. In this research work, novel composites of polyaniline with maize bran, wheat bran and rice bran have been synthesized, characterized and employed for batch wise adsorption of $\mathrm{Pb}$ (II) from water. FT-IR technique was used for surface analysis of adsorbents. Various operational conditions of adsorption process like agitation time, $\mathrm{pH}$, adsorbent dose, particle size of composites and temperature were optimized for isothermal and thermodynamical investigations. Maximum adsorption capacity values for polyaniline composites with maize bran, wheat bran and rice bran were 18.75 , 28.93 and $30.11 \mathrm{mg} / \mathrm{g}$ of adsorbent, respectively. Negative $\Delta \mathrm{G}^{\mathrm{o}}$ values for adsorption of $\mathrm{Pb}(\mathrm{II})$ on these composites showed spontaneity of adsorption process. These results showed that maize bran, wheat bran and rice bran modified the external morphology of polyaniline by precluding its aggregation and enhancing its adsorption capacity.

Key Words: Pb(II), Isotherms, Polyaniline, Composites, Maize bran, Wheat bran, Rice bran.

\section{INTRODUCTION}

Polyaniline (PANI) and its composites becoming popular in recent years, due to their ease of synthesis, low economics, good environmental stability, distinctive physicochemical behaviour and various practical applications like transistors, integrated circuits, batteries, electrical or optoelectronic devices and sensors ${ }^{1,2}$. These polymer composites carry large amounts of various functional groups, especially amine and imine, which are responsible for their adsorptive nature due to chelating nature. Several researchers had investigated polyaniline and its composites as adsorbents for removal of metal ions like $\mathrm{Cr}^{6+}, \mathrm{Hg}^{2+}, \mathrm{Pb}^{2+}, \mathrm{Ag}^{+}$and $\mathrm{Cd}^{2+}$, anions like fluoride ions, cationic dyes and humic acid from aqueous solutions ${ }^{3-10}$. The general molecular structure of sole polyaniline is shown in Fig. 1. Sole polyaniline particles are usually aggregated in aqueous medium, which results in low adsorption capacity due to less surface exposure and slow kinetics. Its adsorption capacity can be improved by blocking its aggregation with some other materials. So, polymerization of aniline carried out in the presence of other low cost materials from agrowaste origin for preventing aggregation of polyaniline.

In this study, novel polyaniline composites were synthesized using maize bran, wheat bran and rice bran and then employed for adsorbing lead(II) from water. Lead compounds are generally use in paints and pigments, supply pipelines,

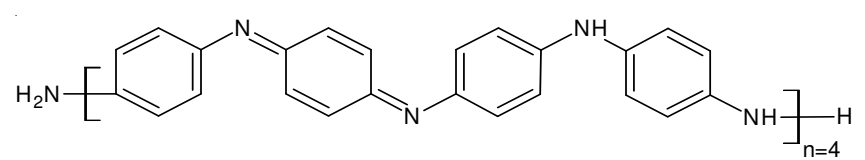

Fig. 1. General molecular structure of polyaniline

storage batteries and additives in gasoline products. Lead is one of the most harmful inorganic pollutants because once it enters into an organism body through any source, it disperses throughout the body immediately and produces dangerous effects where ever it settles down. Some examples are damaging of red blood cells by limiting their ability to carry oxygen to the organs and tissues, lethal affects on nervous system, kidneys and hearing. Particularly fetus and young children are at more risk of health problems related to lead poisoning because they are more susceptible to absorb lead ions. Organic lead compounds used in gasoline products are fat-soluble and are more toxic than inorganic lead compounds. Lead containing compounds are generally metabolic poison and enzyme inhibitor. They inhibit the activity of these enzymes, which have vital role in haem synthesis; coproporphyrinogen oxidase (COPRO-O), 5-aminolaevulinate dehyratase (ALA-D) and ferrochelatase (FERRO-C). So, inhibition of these enzymes activity leads to abnormal concentrations of haem precursors in blood and urine. General methodologies adopted for waste water treatment having lead(II) ions are chemical reduction, 
electrochemical treatment, ion exchange, precipitation, reverse osmosis and adsorption. Adsorption is better option than other processes due to its effectiveness, economical and versatile mode $^{11-16}$.

In this research work; novel composites of polyaniline with agrowaste materials like maize bran, wheat bran and rice bran were synthesized, characterized and their adsorption tendencies for removal of lead(II) from water had been compared. Various operational conditions were optimized and applied for isothermal and thermodynamical modeling of equilibrium data. For regeneration of adsorbents, desorption studies were carried out using different acids. Optimized operational parameters were adopted for treating industrial waste water effluent.

\section{EXPERIMENTAL}

All chemicals like $\mathrm{NaCl}$, aniline, $\mathrm{K}_{2} \mathrm{Cr}_{2} \mathrm{O}_{7}, \mathrm{HCl}, \mathrm{HNO}_{3}$, $\mathrm{H}_{2} \mathrm{SO}_{4}, \mathrm{CH}_{3} \mathrm{COOH}, \mathrm{NaOH}, \mathrm{Pb}\left(\mathrm{NO}_{3}\right)_{2}$ used during this study were of analytical grade and obtained from Merck (Germany). Double distilled water was consumed for all preparations of solutions. Maize bran, wheat bran and rice bran were purchased from local markets and grinded to 60 ASTM particle size.

Electric grinder (Ken Wood), pH meter (HANNA pH 211), Balance ER-120A (AND) and flame atomic absorption spectrophotometer (Perkin Elmer AAnalyst 100) equipped with air-acetylene flame were used in these studies.

Synthesis of standards and working solutions: Stock solution of $\mathrm{Pb}$ (II) ions of $1000 \mathrm{ppm}$ concentration was prepared by dissolving $1.598 \mathrm{~g}$ of $\mathrm{Pb}\left(\mathrm{NO}_{3}\right)_{2}$ per liter of double distilled water. Standards and working solutions were prepared by further dilutions of stock solution.

Synthesis of polyaniline composites: For preparing polyaniline/maize bran (PANI/M.B.) composites, $100 \mathrm{~mL}$ of $2 \mathrm{~mol} \mathrm{~L}^{-1} \mathrm{HCl}$ was mixed with $10 \mathrm{~mL}$ aniline with constant gentle stirring and placing this into a freezing mixture of ice and $\mathrm{NaCl}$ in an ice bath at $0^{\circ} \mathrm{C}$, followed by drop wise addition of $20 \mathrm{~mL}$ of $0.1 \mathrm{~mol} \mathrm{~L}^{-1} \mathrm{~K}_{2} \mathrm{Cr}_{2} \mathrm{O}_{7}$ in 45-50 min. During the same time period, $2 \mathrm{~g}$ powdered maize bran was added in this polymerizing mixture slowly. It was stirred continuously for $2 \mathrm{~h}$ and then it was kept in refrigerator at $-10^{\circ} \mathrm{C}$ for $24 \mathrm{~h}$ for complete settling and precipitation of PANI/M.B. composites. During filtration of these precipitates for separation from solution, they were washed with acetone and $2 \mathrm{~mol} \mathrm{~L}^{-1} \mathrm{HCl}$ for removing oligomers, residual monomers and other impurities. These precipitates were oven dried at $50-60{ }^{\circ} \mathrm{C}$ for $48 \mathrm{~h}$. Schematically chemical reaction occurring during synthesis is shown in Fig. 2. Polyaniline (PANI) was synthesized in similar way without adding maize bran. Polyaniline/wheat bran (PANI/W.B.) and polyaniline/rice bran (PANI/R.B.) composites were synthesized in similar fashion replacing maize bran with powdered wheat bran and rice bran, respectively. These synthesized composites were grinded and sieved to get 60 ASTM particle size. Afterward, they were stored in airtight bottles used for further batch adsorption experiments ${ }^{17,18}$.

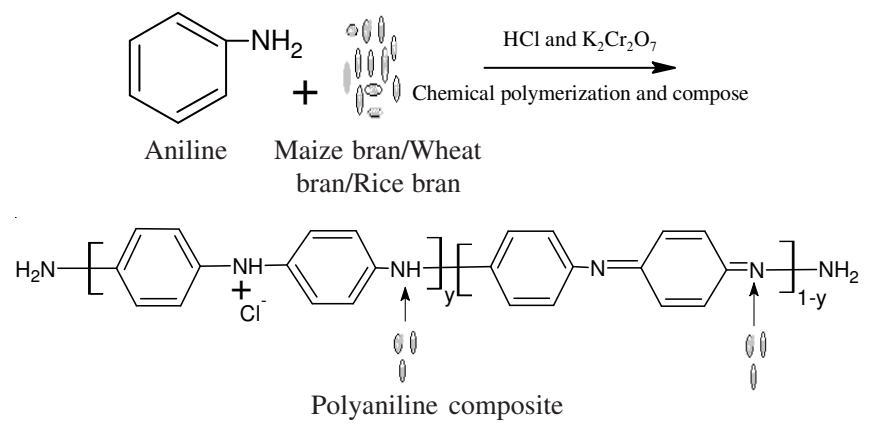

Fig. 2. Schematic Synthesis of polyaniline composites

FT-IR Characterization: FT-IR spectra of polyaniline and composites were recorded with FT-IR spectrophotometer (Perkin Elmer-RXI) in the range of $4000-700 \mathrm{~cm}^{-1}$ for characterizing the surface of all adsorbents. The resulting characteristic vibrational frequencies of various functional groups are given in Table- $1^{17}$.

Batch adsorption experiments and isothermal modeling: Adsorption studies were carried out in batch mode at $25 \pm$ $1{ }^{\circ} \mathrm{C}$. pH of solutions was adjusted with $0.1 \mathrm{~mol} \mathrm{~L}^{-1} \mathrm{HCl}$ and $0.1 \mathrm{~mol} \mathrm{~L}^{-1} \mathrm{NaOH}$. In order to optimizing the effect of adsorbent dose, $\mathrm{pH}$, contact time and temperature, a series of batch experiments were conducted by agitating specified amount of adsorbent in $50 \mathrm{~mL}$ of $\mathrm{Pb}$ (II) ion solution of desired concentration at varying $\mathrm{pH}$ in $250 \mathrm{~mL}$ stoppered flasks. The sample was then filtered and analyzed for remaining $\mathrm{Pb}$ (II) ions concentration by flame atomic absorption spectrophotometer, after calibrating instruments with standard metal ion solutions. The working current/wavelength for $\mathrm{Pb}$ (II) ions was $7.5 \mathrm{~mA} /$ $324.8 \mathrm{~nm}$ for analysis. The percentage adsorption of $\mathrm{Pb}$ (II) ions was determined by the following eqn. 1 :

TABLE- 1

CHARACTERISTIC FT-IR BAND ABSORPTION FREQUENCIES OF POLYANILINE AND ITS COMPOSITES

\begin{tabular}{|c|c|c|c|c|}
\hline \multirow{2}{*}{ Vibrational Assignment } & \multicolumn{4}{|c|}{ Adsorbents } \\
\hline & PANI $\left(\mathrm{cm}^{-1}\right)$ & PANI/M.B. composite $\left(\mathrm{cm}^{-1}\right)$ & PANI/W.B. composite $\left(\mathrm{cm}^{-1}\right)$ & PANI/R.B. composite $\left(\mathrm{cm}^{-1}\right)$ \\
\hline N-H stretching & 3401 & 3411 & 3416 & 3406 \\
\hline Aromatic C-H stretching & 2904 & 2916 & 2913 & 2911 \\
\hline C-NH stretching & 1683 & 1642 & 1693 & 1686 \\
\hline $\mathrm{N}=\mathrm{Q}=\mathrm{N}$ & 1574 & 1586 & 1592 & 1581 \\
\hline $\mathrm{N}=\mathrm{B}=\mathrm{N}$ & 1492 & 1497 & 1496 & 1502 \\
\hline C-N stretching & 1290 & 1297 & 1291 & 1287 \\
\hline $\mathrm{C}=\mathrm{N}$ stretching & 1240 & 1247 & 1238 & 1244 \\
\hline Aromatic C-N-C & 1121 & 1112 & 1106 & 1137 \\
\hline $\mathrm{C}-\mathrm{H}$ in plane & 1036 & 1040 & 1040 & 1037 \\
\hline C-H out of plane & 795 & 791 & 787 & 805 \\
\hline Phenazine like ring by cyclization & 750 & 746 & 748 & 754 \\
\hline $\mathrm{C}-\mathrm{Cl}$ stretching & 682 & 671 & 686 & 687 \\
\hline
\end{tabular}




$$
\text { Adsorption }(\%)=\frac{\mathrm{C}_{0}-\mathrm{C}_{\mathrm{e}}}{\mathrm{C}_{0}} \times 100
$$

Here $\mathrm{C}_{\mathrm{o}}$ and $\mathrm{C}_{\mathrm{e}}$ are the initial and final concentrations of $\mathrm{Pb}(\mathrm{II})$ ions before and after adsorption process, respectively. For isothermal studies, optimized conditions of all above experiments were applied simultaneously to $100 \mathrm{~mL}$ of six solutions of $\mathrm{Pb}(\mathrm{II})$ ions within concentration range of $30-80 \mathrm{ppm}$. At the end, all these solutions were filtered and analyzed for remaining $\mathrm{Pb}(\mathrm{II})$ ions concentration. Langmuir isotherm was plotted using eqn. 2 .

$$
\frac{1}{\mathrm{q}}=\frac{1}{\mathrm{bq}_{\mathrm{m}} \mathrm{C}_{\mathrm{e}}}+\frac{1}{\mathrm{q}_{\mathrm{m}}}
$$

In the above equation ' $\mathrm{q}$ ' (mg/g) is the amount of $\mathrm{Pb}$ (II) ions adsorbed by composites, ' $\mathrm{C}_{\mathrm{e}}{ }^{\prime}(\mathrm{ppm})$ is the remaining concentration of $\mathrm{Pb}(\mathrm{II})$ ions after adsorption experiment, ' $\mathrm{q}_{\mathrm{m}}$ ' $(\mathrm{mg} / \mathrm{g})$ and $\mathrm{b}(\mathrm{L} / \mathrm{g})$ are Langmuir isotherm constants calculated from regression analysis of the linear plots of ' $1 / \mathrm{q}$ ' versus ' $1 / \mathrm{C}_{\mathrm{e}}$. The value of $\mathrm{q}$ is calculated by using eqn. 3 .

$$
\mathrm{q}=\frac{\left(\mathrm{C}_{0}-\mathrm{C}_{\mathrm{e}}\right) \mathrm{V}}{\mathrm{m}}
$$

whereas ' $\mathrm{V}$ ' is the volume of $\mathrm{Pb}$ (II) ions solution in liters and ' $m$ ' is the mass of composites used in grams. Freundlich isotherm was drawn eqn. 4 :

$$
\log \mathrm{q}=\log \mathrm{K}_{\mathrm{F}}+\frac{1}{\mathrm{n}} \log \mathrm{C}_{\mathrm{e}}
$$

In this equation, ' $\mathrm{K}_{\mathrm{F}}$ ' and ' $\mathrm{n}$ ' are Freundlich isotherm parameters, whose values were calculated from slope and intercept of graph of ' $\log q^{\prime}$ versus ' $\log \mathrm{C}_{\mathrm{e}}{ }^{13,15}$. For accuracy, all experiments were performed in triplicates and average values were taken with the experimental error in the range of $0.5-2.5 \%$. Statistical analysis of all data was carried out by Microsoft office Excel 2007 (Microsoft, USA) ${ }^{18}$.

Thermodynamical investigations: Thermodynamic parameter $\Delta \mathrm{G}^{\mathrm{o}}$ (Gibbs free energy change) is determined from equilibrium data using Langmuir isotherm constant ' $b$ ' by eqn. 5:

$$
\Delta \mathrm{G}^{\mathrm{o}}=-\mathrm{RT} \ln (\mathrm{K})
$$

where ' $\Delta G^{\circ}$ ' is the free energy change in $\mathrm{KJ} / \mathrm{mol}$, 'R' is the universal gas constant with the value $8.314 / 1000 \mathrm{KJ}$ mol/ Kelvin, ' $\mathrm{T}$ ' is the absolute temperature in Kelvin and ' $\mathrm{K}$ ' is the reciprocal of Langmuir constant ' $b^{\prime 18,19}$.

Regeneration of adsorbents: Desorption studies were carried out using $10 \mathrm{~g}$ of composites in $100 \mathrm{~mL}$ of $10.0 \mathrm{mmol}$ $\mathrm{L}^{-1}$ solutions of $\mathrm{HCl}, \mathrm{H}_{2} \mathrm{SO}_{4}, \mathrm{HNO}_{3}$ and $\mathrm{CH}_{3} \mathrm{COOH}$ separately in $250 \mathrm{~mL}$ flasks, stirring at $100 \mathrm{rpm}$ for $25 \mathrm{~min}$ at room temperature, i.e., $25 \pm 3{ }^{\circ} \mathrm{C}$. Then regenerated composites were dried in an oven at $80^{\circ} \mathrm{C}$ for $5-6 \mathrm{~h}$ and then reused. The percentage desorption was calculated by using eqn. $6^{18}$ :

$$
\text { Desorption }(\%)=\frac{\mathrm{q}_{\text {des }}}{q} \times 100
$$

Here ' $\mathrm{q}_{\text {des }}$ ' is $\mathrm{Pb}(\mathrm{II})$ ions desorbed and ' $\mathrm{q}$ ' is $\mathrm{Pb}(\mathrm{II})$ adsorbed. ' $\mathrm{q}_{\text {des }}$ ' values were determined from the concentration of $\mathrm{Pb}$ (II) ions desorbed $\left(\mathrm{C}_{\mathrm{des}}\right)$ in the filtrate using eqn. 7 :

$$
\mathrm{q}_{\mathrm{des}}=\mathrm{C}_{\mathrm{des}} \frac{\mathrm{V}}{\mathrm{m}}
$$

Here ' $V$ ' and ' $m$ ' have the same meanings as mentioned earlier.

\section{RESULTS AND DISCUSSION}

Surface characterization of adsorbents: The presence of various chelating type functional groups in polyaniline (PANI) and its composites with maize bran (PANI/M.B.), wheat bran (PANI/W.B.) and rice bran (PANI/R.B.) have been confirmed by recording their FT-IR spectra and resulting vibrational frequencies were compared in Table-1. A peculiar band found in the $1100-1140 \mathrm{~cm}^{-1}$ region in all samples FT-IR spectra due to charge delocalization on the polymer backbone. There is a shift towards higher wave number in vibrational frequencies values of polyaniline after composites formation, which is an indication of physiochemical bonding between polyaniline and agro-waste materials. The vibrational frequency peaks observed at 1574, 1586, 1592 and $1581 \mathrm{~cm}^{-1}$ in PANI, PANI/M.B., PANI/W.B. and PANI/R.B. spectrum correspondingly, are due to the stretching of $\mathrm{N}=\mathrm{Q}=\mathrm{N}$ group, $(\mathrm{Q}=$ quinoid ring), where as the vibrational frequency peaks at 1492, 1497, 1496 and $1502 \mathrm{~cm}^{-1}$ in PANI, PANI/M.B., PANI/W.B. and PANI/R.B. spectrum respectively are due to the stretching of $\mathrm{N}=\mathrm{B}=\mathrm{N}$ group ( $\mathrm{B}=$ benzene ring). The characteristic $\mathrm{N}-\mathrm{H}$ stretching peaks were found at 3401, 3411, 3416 and 3406 $\mathrm{cm}^{-1}$ in that order PANI, PANI/M.B., PANI/W.B. and PANI/ R.B. which are mainly involved in lead ions removal. The peaks due to the aromatic C-H stretching are found at 2904, 2916, 2913 and $2911 \mathrm{~cm}^{-1}$ in PANI, PANI/M.B., PANI/W.B. and PANI/R.B., respectively ${ }^{17-19}$.

Optimization of operational conditions: The adsorption capacities of polyaniline, maize bran, wheat bran, rice bran and all composites was compared in Fig. 3. Polyaniline composites have more adsorption capacity for lead(II) ions as compared to raw materials of these composites. So, in further experiments, operational conditions of adsorption process like adsorbent dose, $\mathrm{pH}$, agitation speed, contact time and temperature were optimized one by one using polyaniline composites.

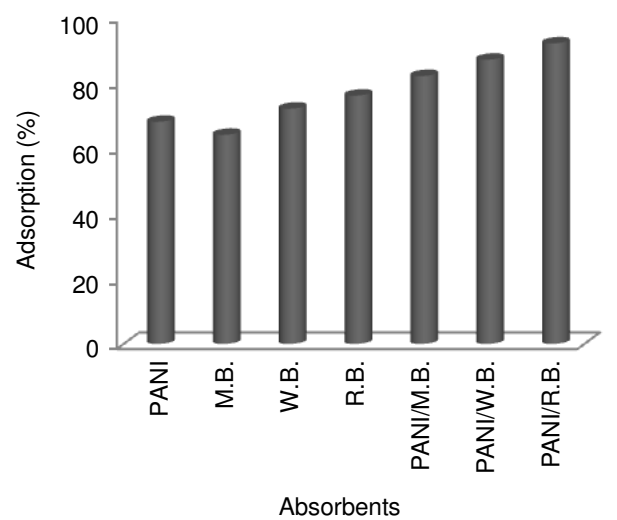

Fig. 3. Comparative adsorption capacity of raw materials and composites for removing $\mathrm{Pb}(\mathrm{II})$ ions

The effect of variation in the adsorbent dose of composites on the percentage adsorption of $\mathrm{Pb}(\mathrm{II})$ was studied and results 
are presented in Fig. 4. The maximum percentage removal values were obtained when the adsorbent dose was 0.9, 0.6 and $0.6 \mathrm{~g}$ using PANI/M.B., PANI/W.B. and PANI/R.B. composites. This increase in adsorption with small adsorbent does in case of polyaniline/maize bran (PANI/M.B.) composites was due to the availability of more adsorption sites.

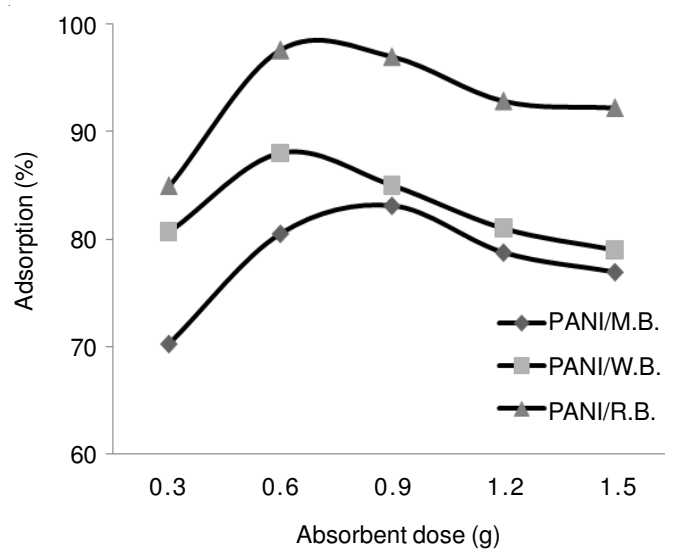

Fig. 4. Effect of adsorbent dose on percentage adsorption of $\mathrm{Pb}$ (II) ions by polyaniline composites

The $\mathrm{pH}$ of the aqueous solution during adsorption process can regulate the charges on the adsorbent binding sites and speciation of metal ions in media. Thus, it is necessary to investigate ionic states of the functional groups of adsorbent and metal ion solution chemistry at different $\mathrm{pH}$ conditions of aqueous solution under treatment. Lead(II) ions precipitations occur in basic conditions, so $\mathrm{pH}$ range of 2-8 was studied. The results are shown in Fig. 5. The maximum adsorption capacity of polyaniline composites for $\mathrm{Pb}$ (II) was observed at $\mathrm{pH}$ 5.0. FT-IR analysis of polyaniline composites showed that they contain functional groups like amino, amido and imino etc. These functional groups are protonated at low $\mathrm{pH}$ and act as positively charged species. Shifting towards higher $\mathrm{pH}$ values results in deprotonation of these functional groups and they become negatively charged species. Now, they can chelate lead(II) ions with them, which results in more adsorption capacity of polyaniline composites ${ }^{13}$.

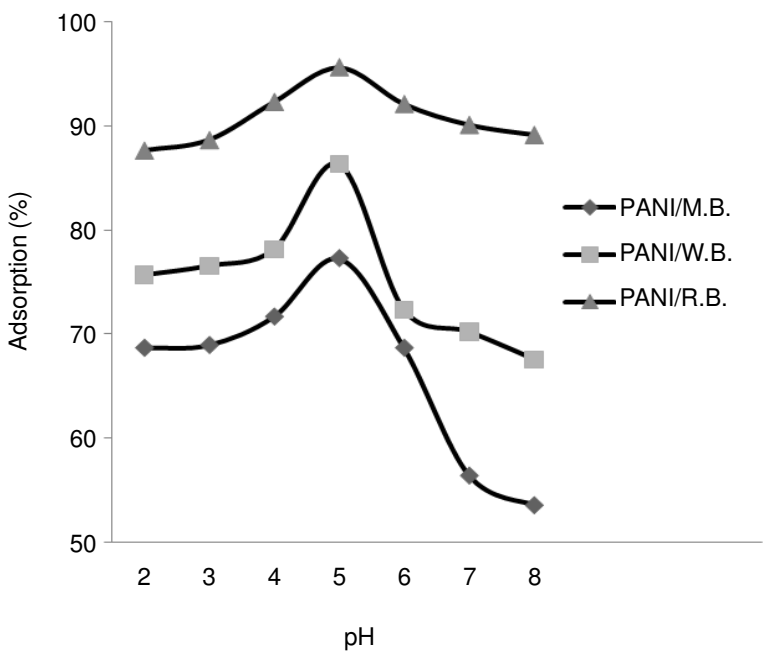

Fig. 5. Effect of $\mathrm{pH}$ on percentage adsorption of $\mathrm{Pb}$ (II) ions by polyaniline composites
The effect of contact time variations on the percentage adsorption of $\mathrm{Pb}$ (II) by PANI/M.B., PANI/W.B. and PANI/ R.B. composites was studied and results are shown in Fig. 6. The maximum percentage adsorption occurs in 0.5 min using PANI/M.B. and PANI/W.B. composites. Whereas using PANI/ R.B. composite, this time interval is further reduced to $20 \mathrm{~min}$ showing that it has more adsorption sites which are available for rapid uptake of $\mathrm{Pb}(\mathrm{II})$ metal ions.

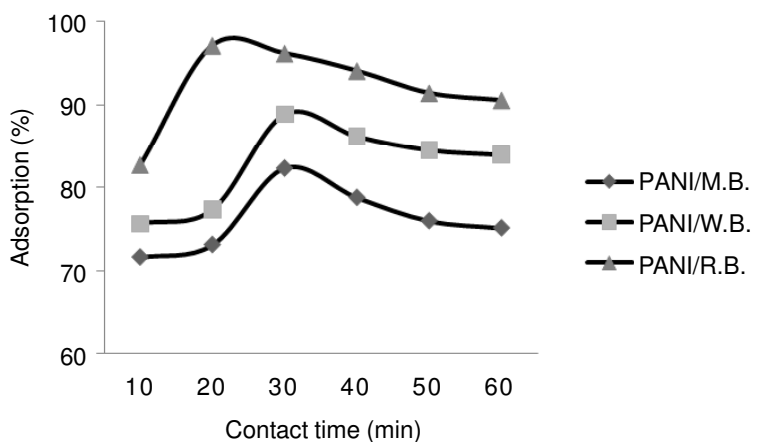

Fig. 6. Effect of contact time on percentage adsorption of $\mathrm{Pb}(\mathrm{II})$ ions by polyaniline composites

Effect of temperature variations on adsorption capacity of PANI/M.B., PANI/W.B. and PANI/R.B. composites for $\mathrm{Pb}$ (II) was studied at various temperatures ranging $20-70{ }^{\circ} \mathrm{C}$ and results are presented in Fig. 7. Maximum $\mathrm{Pb}(\mathrm{II})$ adsorption occur at $30{ }^{\circ} \mathrm{C}$ using PANI/M.B. and PANI/W.B. composites and at $40^{\circ} \mathrm{C}$ using PANI/R.B. composite. At higher temperatures, decrease in adsorption was observed due to the fact that in high temperature conditions, solvent molecules move with greater speed and less time of interaction was available for lead(II) with composites binding sites ${ }^{8}$.

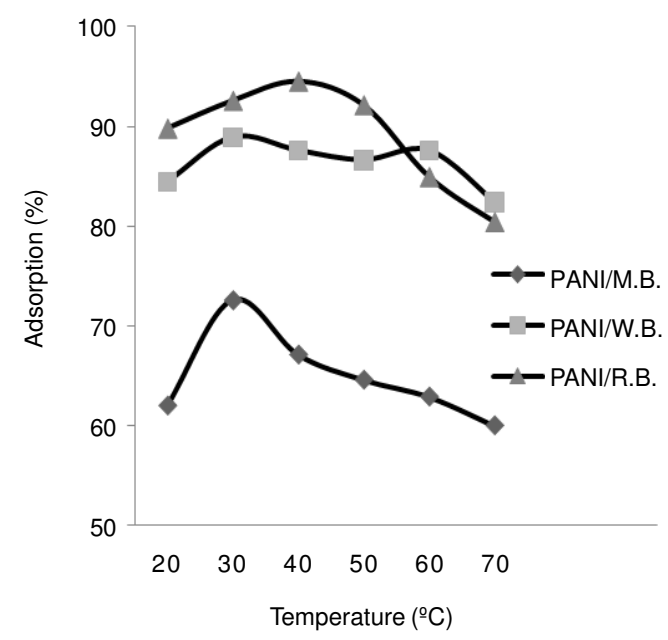

Fig. 7. Effect of temperature on percentage adsorption of $\mathrm{Pb}$ (II) ions by polyaniline composites

Mechanistic studies by isothermal modeling: Using all the optimized conditions for adsorption of lead(II) by PANI/ M.B., PANI/W.B. and PANI/R.B. composites, isothermal studies were carried out using higher concentration of metal ions and results are shown in Table- 2 for Langmuir and Freundlich isotherms. The correlation coefficients $\left(\mathrm{R}^{2}\right)$ values showed that Langmuir isotherm model is more applicable to 
TABLE- 2

ISOTHERMAL AND THERMODYNAMICAL PARAMETERS FOR ADSORPTION OF PB(II)

\begin{tabular}{|c|c|c|c|c|c|c|c|c|c|c|c|}
\hline \multirow[t]{2}{*}{ Adsorbents } & \multicolumn{5}{|c|}{ Langmuir isotherm parameters } & \multicolumn{5}{|c|}{ Freundlich isotherm parameters } & \multirow{2}{*}{$\begin{array}{c}\text { Thermodynamical } \\
\text { parameter } \\
\Delta \mathrm{G}^{\mathrm{o}}(\mathrm{KJ} / \mathrm{mol})\end{array}$} \\
\hline & Slope & Intercept & $\mathrm{R}^{2}$ & $\mathrm{q}_{\mathrm{m}}(\mathrm{mg} / \mathrm{g})$ & $\mathrm{b}(\mathrm{L} / \mathrm{g})$ & Slope & Intercept & $\mathrm{R}^{2}$ & $\mathrm{~K}_{\mathrm{F}}$ & $\mathrm{n}$ & \\
\hline PANI/M.B & 0.469 & 0.053 & 0.984 & 18.75 & 0.114 & 0.292 & 0.726 & 0.982 & 5.32 & 3.430 & -5.381 \\
\hline PANI/W.B & 0.581 & 0.035 & 0.985 & 28.93 & 0.059 & 0.430 & 0.627 & 0.977 & 4.23 & 2.325 & -7.012 \\
\hline PANI/R.B & 0.428 & 0.033 & 0.986 & 30.11 & 0.078 & 0.371 & 0.770 & 0.979 & 5.89 & 2.695 & -6.32 \\
\hline
\end{tabular}

equilibrium data as compared to Freundlich model. This indicates the homogeneous distribution of active binding sites for adsorbate on the PANI/M.B., PANI/W.B. and PANI/R.B. composite surface, which results in monolayer chemisorption of $\mathrm{Pb}$ (II) ions. Maximum adsorption capacities, ' $\mathrm{q}_{\mathrm{m}}$ ' values were 18.75, 28.93 and $30.11 \mathrm{mg} / \mathrm{g}$ for PANI/M.B., PANI/W.B. and PANI/R.B. composites, respectively. This shows that these polyaniline composites had greater potency for lead waste water treatment. Fig. 8 is showing the predicted mechanism of $\mathrm{Pb}$ (II) ions adsorption on PANI/M.B., PANI/W.B. and PANI/ R.B. composites. In this figure, $\mathrm{Cl}^{-}$ions are doped in composites during synthesis process. It is a well established fact that nitrogen-containing functional groups can easily coordinate with metal ions. Langmuir model applicability on equilibrium data also support this fact that the removal of $\mathrm{Pb}(\mathrm{II})$ ions occurred mainly due to chemisorption in monolayer fashion on the surfaces of composites ${ }^{18}$.

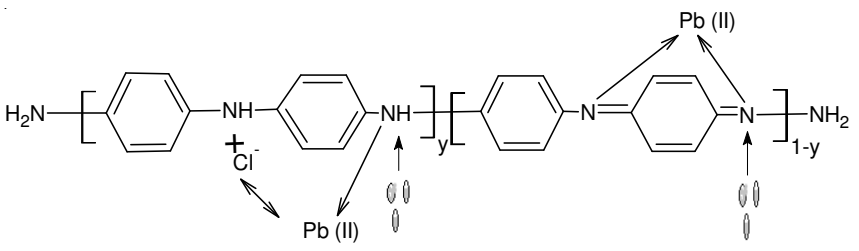

Fig. 8. Mechanism for $\mathrm{Pb}(\mathrm{II})$ ions removal by polyaniline composites

Freundlich isotherm constant ' $\mathrm{K}_{\mathrm{F}}$ ' is known as binding constant, which is related to the adsorption capacity of composites. Its values for PANI/M.B., PANI/W.B. and PANI/R.B. composites were 5.32, 4.23 and 5.89 correspondingly. The second Freundlich isotherm constant ' $n$ ' is related with adsorption intensity of composites. Its value less than 8.0 means good adsorption intensity and it varies with heterogeneity of the adsorbing surface. Its values were 3.430, 2.325 and 2.695 for PANI/M.B., PANI/W.B. and PANI/R.B. composites respectively ${ }^{11,15}$.

Thermodynamical investigation: The Gibbs free energy of adsorption $\left(\Delta \mathrm{G}^{\circ}\right)$ of $\mathrm{Pb}$ (II) ions on composites was calculated from the Langmuir constant ' $b$ ' and its values were -5.381 , -7.012 and $-6.32 \mathrm{KJ} / \mathrm{mol}$ for PANI/M.B., PANI/W.B. and PANI/R.B. composites, respectively as clear from Table-2. These negative values predicts the feasibility and spontaneity of adsorption process with greater removal of $\mathrm{Pb}(\mathrm{II})$ with polyaniline composites, which is confirmed by isothermal modeling of equilibrium data and ' $\mathrm{q}_{\mathrm{m}}$ ' values for composites ${ }^{18,19}$.

Desorption Studies: For regenerating used composites, they were treated with different acids and results are presented in Fig. 9. From these results, it was found that hydrochloric acid is a good desorbing chemical for all composites as compared to nitric acid, sulphuric acid and acetic acid. The

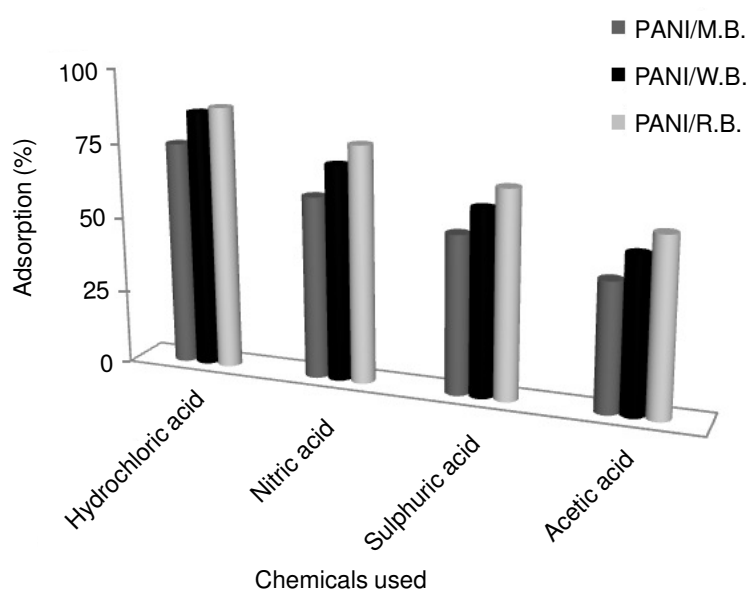

Fig. 9. Desorption studies of $\mathrm{Pb}$ (II) ions from polyaniline composites using different chemicals

regenerated adsorbents can be reused for adsorption with a little decrease in adsorption capacity.

Real industrial effluent treatment: Optimized conditions of adsorption were employed to conduct a batch experiment with real sample of industrial effluents from lead storage batteries forming industries near Lahore. There was little decrease in maximum adsorption capacity values due to the presence of other metal ions in effluents which can compete for binding sites on composites. Adsorption capacity values for PANI/ M.B., PANI/W.B. and PANI/R.B. composites were 17.13, 25.86 and $26.54 \mathrm{mg} / \mathrm{g}$, respectively.

\section{Conclusion}

From this study, it is concluded that the formation of polymer composites with maize bran, wheat bran and rice bran efficient improved its adsorption capacity. Isothermal studies showed that chemisorption occurred during removal of lead(II) ions by composites. Maximum adsorption capacity was shown by polyaniline/rice husk composites, i.e., $30.11 \mathrm{mg} / \mathrm{g}$. The spontaneity and feasibility of the adsorption process using polyaniline and its composites was confirmed by negative values of $\Delta \mathrm{G}^{\mathrm{o}}$. Hydrochloric acid was found a good desorbent for regenerating composites. Real industrial waste water treatment proves the effectiveness of this work on industrial scale.

\section{REFERENCES}

1. Z.M. Tahir, E.C. Alocilja and D.L. Grooms, Biosens. Bioelectron, 20, 1690 (2005).

2. A. Pud, N. Ogurtsov, A. Korzhenko and G. Shapoval, Prog. Polym. Sci., 28, 1701 (2003).

3. R.K. Gupta, R.A. Singh and S.S. Dubey, Sep. Purif. Technol., 38, 225 (2004).

4. Z. Sadowski, Miner. Eng., 14, 547 (2001).

5. A.G. Yavuz, E.D. Atalay, A. Uygun, F. Gode and E. Aslan, Desalination, 279, 325 (2011). 
6. M.R. Samani, S. Borghei, A. Olad and M.J. Chaichi, J. Hazard. Mater., 184, 248 (2010).

7. J.W.X. Han, H. Ma, Y. Ji and L. Bi, Chem. Eng. J., 173, 171 (2011).

8. Q. Li, L. Sun, Y. Zhang, Y. Qian and J. Zhai, Desalination, 266, 188 (2011).

9. M.A. Salem, React. Funct. Polym., 70, 707 (2010).

10. L.H. Ai, J. Jiang and R. Zhang, Synth. Met., 160, 762 (2010).

11. V.S. Munagapati, V. Yarramuthi, S.K. Nadavala, S.R. Alla and K. Abburi, Chem. Eng. J., 157, 357 (2010).

12. Internal Programme on Chemical Safety, Environmental Health Criteria 165: Inorganic Lead, Geneva, World Health Organization, p. 220 (1995)

13. X.M. Zhan and X. Zhao, Water Res., 37, 3905 (2003).
14. M. Momcilovic, M. Purenovic, A. Bojic, A. Zarubica and M. Randelovic, Desalination, 276, 53 (2011)

15. M. Sekar, V. Sakthi and S. Rengaraj, J. Colloid Interf. Sci., 279, 307 (2004).

16. B. Yu, Y. Zhang, A. Shukla, S.S. Shukla and K.L. Dorris, J. Hazard. Mater., 84, 83 (2001).

17. F. Kanwal, R. Rehman, J. Anwar and M. Saeed, J. Chem. Soc. Pak., 34, $1134(2012)$.

18. F. Kanwal, R. Rehman, J. Anwar and T. Mahmud, EJEAFChe, 10, 2972 (2011).

19. N.A. Oladoja, I.O. Asia, C.O. Aboluwoye and Y.B. Oladimeji, Turk. J. Eng. Environ. Sci., 32, 303 (2008). 